\title{
Memory, Kinship, and the Mobilization of the Dead: The Russian State and the "Immortal Regiment" Movement
}

\author{
Julie Fedor
}

The 2015 jubilee celebrations of the Red Army's Victory over Nazi Germany were marked by the arrival of a new mass commemorative ritual, a striking addition to the repertoire of Victory Day traditions in post-Soviet space. In the newly invented annual "Immortal Regiment" parade, people march bearing photographs of their ancestors who fought or otherwise served the Soviet war effort in the Great Patriotic War of 1941-1945. In this new ritual, participants take their ancestors'

The research for this chapter was supported under the Australian Research Council's Discovery Early Career Research Awards (DECRA) funding scheme (project DE150100838). The fee for making the chapter available via Open Access was also covered by the same grant. The views expressed herein are those of the author and are not necessarily those of the Australian Research Council. A German version of this chapter was published in Osteuropa 5 (2017): 61-85. We are grateful to Osteuropa's editors for permission to reprint it here.

J. Fedor $(\bowtie)$

University of Melbourne, SHAPS, Arts West, Parkville, Victoria 3010, Australia

e-mail: julie.fedor@unimelb.edu.au

(C) The Author(s) 2017

J. Fedor et al. (eds.), War and Memory in Russia, Ukraine and Belarus, DOI 10.1007/978-3-319-66523-8_11 
photographs out of their family albums or cardboard boxes, or off the wall at home. They reproduce the photos, making enlarged copies that are then laminated, mounted onto little placards on sticks, and carried overhead by the participants in procession. Bobbing above the heads of the marchers, the deceased ancestors are brought back to life, and their gathering together makes for an impressive spectacle, enabling a kind of visualization of the otherwise unimaginably huge losses sustained by the Soviet Union during the war. The Immortal Regiment made its most spectacular debut during the 2015 jubilee Victory Day celebrations marking the 70th anniversary of the end of the war. As part of the celebrations, the Regiment was granted permission to march across the country's most sacred war memory site, Red Square, and President Putin himself joined the parade, bearing a photograph of his father. The number of people taking part in the Immortal Regiment on Victory Day 2015 reportedly reached twelve million, or, as self-appointed leader of the "Immortal Regiment of Russia" (BPR) movement Nikolai Zemtsov noted, more than thirty million if you count the dead who took part (cited Golubeva 2015b).

The BPR's organizers argue that this movement represents "a new reading" of the Soviet Victory in the war (ibid.). "Never before," the BPR website proclaims, "has the meaning and grandeur of the Victory holiday been revealed so completely and deeply" (BPR n.d). Clearly, this is a movement that enjoys massive popularity and that represents a significant shift in the way in which Russia's war dead are commemorated, and yet the nature and meaning of this shift remains a very open question. The advent of the Immortal Regiment has sparked lively online and offline discussions over the meaning, the ethics, and the aesthetics of the new ritual. Should it be read as a symptom of the post-Crimean militarization of Russian society, or a healthy sign of a grassroots revival of family memory (see Reut 2016)? Does it represent a shift away from the heroic Victory cult towards a new emphasis on mourning the war's victims (Starikov 2015b), or is it rather a "mass death cult" reflecting a morbid fixation on the dead (Babchenko 2016)? What is the relationship between this movement to commemorate the victims of war and the forgetting of the victims of state terror (see Bessmertnyi barak n.d)? ${ }^{1}$ Is the movement doomed to be "bureaucratized" and taken over by the state, or might it, on the contrary, potentially mark the new beginnings of an independent civil society in Russia based on shared respect for the value of human life, representing a nascent participatory historical culture, 
perhaps along the lines described by David Thelen, who posits that such a culture can help people "to reach from the personal to the collective" (Thelen 1998)? $?^{2}$

The debates reflect the way in which the Immortal Regiment movement has become a battleground for redefining not just the meaning of Victory Day, but also much larger questions relating to state-society relations; the nature of the connections between family/national and individual/collective memories; and broader attitudes to warfare and violence, past and present. In this chapter, I examine one strand of the discursive representations of the Immortal Regiment phenomenon: the new meanings that the Russian state authorities and their supporters are weaving around this movement. Extravagant claims have been made with regard to the significance of the Immortal Regiment phenomenon. It has been hailed as a "truly popular and inter-ethnic movement" (Golubeva 2015a); and "an ideology, perhaps even a national idea" by United Russia Moscow City Duma deputy and director of the Museum of Contemporary Russian History Irina Velikanova (cited in Vinokurov 2015). It has even been described by the organizers as representing "a new reality" (Golubeva 2015b). What, then, are the defining features of this new reality, this ideology? How is this new tradition being used, and to what ends? What kinds of visions of Russia's past, present, and future are presented here?

My account focuses on the attempts to instrumentalize the new Immortal Regiment ritual and to appropriate the Red Army's war dead, and the emotions they evoke, in the service of an authoritarian vision of the future of Russia and the region. I trace out the key themes and tropes in the pro-Kremlin interpretations of this new memory practice and show how the redrawing of boundaries between the living and the dead that is performed by the Immortal Regiment also entails the creation of other sets of new boundaries: between patriotic citizens and "enemies," and "fascists" and "anti-fascists"; legitimate and illegitimate uses of public space; authentic and inauthentic manifestations of civil society; and between "real" eternal spiritual borders and "artificial" postSoviet geopolitical borders. The creation of these borders is performed and enacted by the figure of the dead Red Army soldier, who is being brought back to life in new ways as part of the current regime's authoritarian project. I focus in particular on the ways in which the advent of the Immortal Regiment is being claimed as evidence of near-unanimous 
support for the Putin regime, not only among the living, but also among the nation's war dead.

\section{Performing Memory, Kinship, and Nationhood}

The Immortal Regiment parade is an obvious example of a performative act of memory, one that uses "the language of the past to say something about the present," not just with a view to describing but also with making something happen, as in John Austin's use of the term "performative" (Burke 2010: 105-106). Erll and Rigney note that remembering is an active process of engagement with the past that is performative rather than merely reproductive, "as much a matter of acting out a relationship to the past from a particular point in the present as it is a matter of preserving and retrieving earlier stories" (Erll and Rigney 2009: 2). In the case of the Immortal Regiment ritual, the relationships to the past being performed here revolve primarily around notions of kinship.

One of the reasons why the Immortal Regiment became a media sensation in May 2015 was the fact that President Putin himself joined the parade, bearing a photograph of his father. For many commentators, in taking part in the parade, Putin was taking up his position as head of the Russian nation as family, and thus enacting a moment of consolidation of national unity. As Nikolai Zemtsov put it, "[Through the Immortal Regiment] we've shown that we are one family, the head of which has now been taken up by the president, who showed that he is a person like everyone, he spoke about the link of his simple papa-soldier with the country" (cited in Neroznikova 2015). Elsewhere too, Zemtsov linked the emotions called up by the parade to a newly awakened sense of national kinship. He commented that, "Those who love Russia rejoiced and wept from the excess of feeling. Those who came also felt this extraordinary unity-they felt themselves part of a big family, part of a nation. Of a nation like a family" (Golubeva 2015b).

The trope of nation as family is of course a staple of all nationalist discourse (see further Verdery 1999), and most nations define themselves by tracing their origins to foundational wars (Soltysik Monnet 2012). Yet at the same time, as Jan Assmann (2011:4) notes, the differences in the ways that societies remember play a crucial role in shaping cultures and identities. What, then, is distinctive about this particular national kinship model, and the particular forms of remembering and narrating the war upon which it draws? 
It is the distinctive use of the Red Army soldier that I wish to highlight here, in particular, the ways in which the Red Army soldier is framed as a mythical progenitor and a shared forefather for all the peoples of postSoviet space. Thus for example the website of the Immortal Regiment movement proclaims that children, present and future, "are all offshoots from that mighty root-the soldier who conquered Evil" (Lapenkov n.d). Through crowdsourcing family histories via the movement's online historical databases, the organizers hope that "the soldier himself will become a center, clamping together kinship bonds" (ibid.)—presumably an allusion to Putin's famous December 2012 speech in which he lamented the lack of "spiritual clamps" holding together contemporary Russian society (Putin 2012).

The Red Army soldier is sometimes coded as Russian, and sometimes in supranational terms, as the representative of a universal antifascist mission; often both associations are present simultaneously. ${ }^{3}$ In this way the discourse mixes together elements of Soviet internationalism and supra-ethnic messianism, primordialist ethnic nationalism, and neo-imperialism. Its eclectic nature mirrors the varied trajectory of the development of post-Soviet-Russian nationalism more broadly, which as Pål Kolstø (2016) describes, has oscillated between imperialist, ethnonationalist, and statist tendencies, sometimes combining features of each.

The framing of the Red Army hero as a common ancestor offers a powerful way to connect the official cult of the Great Victory and the private family memories of wartime loss and suffering; and also to assert a connection between the Russian Federation and the rest of the "Russian world," discursively constructed as a space that is saturated and sanctified by the Red Army's blood. Consider for example the following statement by Nikolai Zemtsov, in an interview about the Immortal Regiment, in which he said that even though official state borders had changed since 1945 ,

the space of the spirit has been preserved. Good memory will allow future generations to sew the hems of geo-politics back together. This year's celebration of ... Victory... showed that this is so... The power of jointly split blood places big obligations on the descendants. (cited in Golubeva 2015b)

In this way, the blood shed by soldiers of different nationalities in the Soviet army is said to bring into being a different set of "spiritual" borders. 
These in turn are used to justify Russian implied claims to territory elsewhere in post-Soviet space, in a discursive move signaling Russian revisionist and expansionist intentions.

The writings of pro-Kremlin publicist Roman Nosikov represent one of the more extreme varieties of this nationalist kinship discourse. Here we see a biological discourse in which the blood of the Red Army soldiers shed during the war acted as a "seed" that brought forth the Russian nation:

In our birth a role was played not only by the seed of the fathers but also by the blood of the great-grandfathers ... we are one family. We were conceived by blood [ $M y-z a c h a t y e ~ k r o v ' i u-t h e$ Russian term zachatye has an exclusively biological meaning-JF]. (Nosikov 2015: 126)

Nosikov's writings on this topic also have an occultist tinge. Consider, for example, the image he deploys of a Red Army soldier from the Great Patriotic War who stands behind the "curtain" of reality watching the present unfold, his breath causing the curtain to sway from time to time, but who can only be seen by Russians (ibid.: 77). Nosikov writes that: "When a Russian looks at the world, he always see behind it this silent motionless figure, and he knows that at any moment this figure might pull the world off to one side, as though pulling back a curtain, and step to meet us" (ibid.). This trope of the undead Red Army soldier, existing in a kind of parallel reality whence he observes and exerts a mysterious influence over current events, is a recurring motif in contemporary Russian treatments of the war theme, such as the controversial "social advertisement" produced in the lead-up to Victory Day 2016 which featured the ghost of a child soldier ("Samarskii 'Yeralash" 2016).

Another distinctive aspect of the nationalist kinship model linked to the Immortal Regiment movement is the fact that poiskoviki, members of volunteer search detachments who take part in expeditions aimed at finding the bodies of missing soldiers, are granted a special honorary kinship status as surrogate blood relatives by virtue of their role in discovering, exhuming, identifying, and reburying fallen soldiers. Whereas normally participants in the Immortal Regiment are supposed to carry portraits of their family members, in the event that relatives are unable to take part, poiskoviki have the right to march on their behalf, according to the Immortal Regiment coordinator in Rostov (Gorodskoi reporter 2016). 
Much emphasis was placed by Putin, and, following his cue, by pro-Kremlin media, on the fact that he was taking part in the Immortal Regiment parade as an ordinary citizen and specifically as the son of a "simple soldier." In an interview following the event, Putin said:

I think that my father, just like millions and millions of simple soldiers, he was simply a simple soldier, had the right to march across this square... And hundreds of others, and thousands of other simple people, simple soldiers, laborers of the rear, can now take their place on Red Square... they've earned this (cited in "Putin proshel po Moskve" 2015).

Putin thus framed the parade as a democratization of Victory Day, a long overdue restoration of justice and recognition of the ordinary anonymous soldier, exemplified by his own father. As Nataliya Danilova has pointed out, the official component of the Victory Day tradition, the military parade across Red Square, is noted for its exclusivity (Danilova 2015: 195). But now, by participating in the Immortal Regiment, ordinary people gained access to Red Square, the symbolic heart of the country and of the Victory myth (see Buckler and Johnson 2013: 3-6). This democratization of Victory Day represents a reverse shift to the one described by Catherine Merridale in her account of the reframing of the Victory through a military parade on Red Square in June 1945 which, she argues, was aimed at reasserting military hierarchy and state control over commemoration of the war (2010: 508). Here we see a declared move in the opposite direction, with Putin descending from the heights of power to merge with the crowd, and a deliberate avoidance of references to ranks or hierarchy of any kind. As pater familias of the nation, Putin also stands in for the anonymous mass soldier, thus forming a bridge between the state and the narod.

\section{May: A Day of Mourning or Celebration?}

The debates around the Immortal Regiment throw into sharp relief one of the basic questions that have always dogged the Victory Day commemorative date: what should be the appropriate mix of celebration and mourning, of triumph and trauma? This is a question that has accompanied rituals of war commemoration in many parts of the globe, particularly in the wake of the post-World War II shift towards remembering war as violence and victimhood rather than heroism and glory (on which see Confino 2005; 
Winter 2006; Bessel 2010). The ANZAC Day ceremonies in Australia, for example, have repeatedly been the subject of heated debates over how to delineate between honoring the memory of the dead and glorifying war (see Thomson 2013: 155). But these issues are especially acute when it comes to Victory Day in post-Soviet space. In addition to the controversies over this date in countries occupied by the Red Army after the war, or facing the threat of Russian aggression today, the issue is also divisive within Russia itself and raises sharp issues about the nature of the obligations structuring relations between state and society and the admissibility of challenging the Great Patriotic War myth and its taboos. The topic of the scale of the massive Soviet war losses, for example, has always been sensitive because it raises the fraught question of responsibility for the Red Army's exceptionally high casualty rate, as well as the issue of the Soviet state's long neglect of many of its war dead, of their burial sites and their bereaved families.

In theory, mourning and celebration are divided neatly on the Russian commemorative calendar, which features two key dates designated for these ends: 22 June, the Day of Memory and Mourning, marking the anniversary of the German invasion of 1941; and 9 May, when the Victory of 1945 is celebrated. But in practice the emotional division of labor between these twin poles is not so easy to achieve, and instead it is generally acknowledged, as Putin did in his 2016 Victory Day address, that Victory Day represents "a ceremony in which joy, memory, and mourning are merged together as one" ("Vladimir Putin" 2016). The mourning and the celebration cannot and indeed must not be fully separated; as Russian Minister for Culture Vladimir Medinskii has put it, "the most important law of Russian history proclaims that any 22 June must always end with a 9 May" (Medinskii 2016). Trauma must always ultimately be transformed into triumph-this is a key message in the official discourse in keeping with the increasingly "upbeat" tone of Victory Day celebrations under Putin.

But for some patriotic commentators, the emergence of the Immortal Regiment parade has destabilized the conventional 22 June/9 May division in ways that endanger national unity. Neo-Stalinist author Nikolai Starikov, for example, was alarmed by what he saw as the inappropriately mournful tone of the new ritual. Starikov argued that this not only marked an unacceptable departure from the Victory Day traditions laid down by the war heroes but was surely an element of the ideological warfare being waged against Russia by the United States, aimed at 
destroying Russian morale and identity. It was right and fitting to mourn the nation's war dead, but this should be done exclusively on 22 June. Victory Day, by contrast, was the day when people "celebrate the power of their spirit, the power of their victory, the might of their derzhava" (Starikov 2015b). Popular patriotic blogger burckina_faso ${ }^{5}$ likewise complained that the Immortal Regiment represented:

the re-formatting of the shared Victory (triumph) into a personal tragedy... Whereas previously on this day people walked with their heads proudly held high, like victors or the descendants of victors, nowadays they are forced to march with a tragic expression on their face, suitable for a funeral procession. (burckina_faso 2016)

For adherents to this hardline position, to mourn the victims of war on Victory Day is to submit to national humiliation.

\section{State And Civil Society}

The debates around the Immortal Regiment speak to one of the research questions posed by Mischa Gabowitsch as part of his major ethnographic project on Victory Day: whose holiday is this? (Gabowitsch 2015). Much of the media discussion around the Immortal Regiment has hinged on the question of the relationship between the state and the grassroots elements of this ritual and of Victory Day commemorations more broadly.

A closer look at the history of the Immortal Regiment movement reveals a story of competing and disputed genealogies. There are in fact two separate movements, with very similar names: "Immortal Regiment" (moypolk.ru) and "Immortal Regiment of Russia" (polkrf.ru). ${ }^{6}$ The latter is a state-affiliated "clone" organization set up with the aim of displacing and/or taking over the original grassroots movement (see further Sergei Parkhomenko 2015; “O situatsii” n.d; Gabowitsch 2016). The original Immortal Regiment movement was the initiative of a small group of journalists, historians by education, who were friends and colleagues working for the Tomsk TV station TV-2 (the station that was closed down in February 2015) (Nordvik 2015). The group shared fond memories of Victory Day from the Soviet period as the "main family holiday," as well as an aversion to the form that Victory Day had taken from the mid-2000s, which they found commercialized and crass. As one of the founders Sergei Lapenkov put it, "Purity and sincerity had 
disappeared, and so we tried to make Victory Day come to life again" (cited ibid.). The group came up with the idea of using photographs of deceased war veterans and marching with them, partly as a means of reinserting veterans into the commemoration in a context when so few living veterans remained; and also with the aim of strengthening the institution of the family by fostering a renewed interest in family history. When they ran a trial version of this event in Tomsk in 2012, it proved very popular, and they subsequently began to be put under pressure by state officials seeking to impose their own preferred leaders on the movement (Parkhomenko 2015). The journalists immediately realized that they needed urgently to set down principles in order to defend the movement's autonomy, and they adopted a statute that specified that this was a non-commercial, non-political movement that was independent of the state (Nordvik 2015). ${ }^{7}$

Subsequently there ensued a battle for control and leadership of this movement, while simultaneously it grew in popularity and spread across different regions of the country (see further Gabowitsch 2016). Officials from the ruling "United Russia" party made attempts to link the party to the movement, in violation of the movement's statutes ("O situatsii" n.d). ${ }^{8}$ Tensions escalated in 2015 with the lead-up to the 70th jubilee celebrations of the end of the war. That year's celebrations were viewed by the government as especially important in the context of Russia's increasing international isolation and deteriorating economic position in the wake of the imposition of Western sanctions over Ukraine. By this time what was effectively a state-affiliated "double" of the Immortal Regiment movement had been set up, with a slightly different name (the Immortal Regiment of Russia, henceforth BPR from the Russian initials). The BPR sought and received support from the Russia-wide Popular Front (ONF) and the Russian Federation's Civic Chamber (Golubeva 2015b), which lobbied the government on its behalf. Celebrities were brought in, and according to Lapenkov, a founding congress was hurriedly convened, without inviting the original activists, and a new leadership then "appointed" at the congress (see Galeeva 2015 and Vinokurov 2015). An especially striking detail of this story is the fact that organizations of poiskoviki, the volunteer "searchers" discussed above who take part in annual expeditions to locate the remains of Red Army soldiers, appear to have been co-opted to help legitimize this founding congress. Indeed, it seems this is why the Smolensk region was chosen, because of its status as the place where the search movement 
first arose in the 1950s (according to Lapenkov, cited Galeeva 2015). ${ }^{9}$ In May 2015 the coordinators of the original movement sent an open letter to Putin setting out their "negative attitude towards the appearance of "Immortal Regiment of Russia" (BPR) ("Bessmertnyi polk" 2016a). However, no response seems to have been forthcoming, and instead the clone movement was evidently given full backing by the state. There were also some signs of a campaign in the media apparently aimed at discrediting the founders of the original Immortal Regiment movement (see for example Golubeva 2015a).

Despite all the advantages that BPR would seem to enjoy, however, in fact the jury is still out on which movement will prevail. According to some reports, at least, the organizers of the Immortal Regiment parades elsewhere in post-Soviet space have tended to show a preference for dealing with the Lapenkov rather than the BPR camp ("My budem delat' svoe delo!” 2016). In Tallinn, veterans' organizations declined to take part in the BPR procession that pro-Russian activist Dmitrii Linter tried to organize in May 2016; instead, they held their own Immortal Regiment ceremony at the local war cemetery, also involving family portraits, but without any procession (Staropopov 2016). Meanwhile, the heads of the BPR and their supporters continue to claim that this is a genuine independent grassroots movement (see for example Golubeva 2015 c). It is precisely by virtue of this claim to be a spontaneous and autonomous movement that the movement retains its value as a source of legitimacy for the state.

In the wake of Victory Day 2016, the organizers of the original Immortal Regiment issued a detailed statement in which they set out their attitude towards the rival BPR and assessed the prospects for their movement's future ("Bessmertnyi polk" 2016a). They noted that there had been numerous violations of their statutes in May $2016 .{ }^{10}$ For example, some schools had forced pupils to take part, thereby also preventing them from marching with their families-something deemed especially objectionable given the movement's mission to bring families closer together. The event had been used by politicians as part of the forthcoming parliamentary election campaigns, and also for commercial profit. A "kitsch" culture was developing around the event ("Bessmertnyi polk" 2016a). Nevertheless, the organizers concluded that:

Despite all this, for the overwhelming majority of Russia's towns and villages, the Regiment has become a voluntary, honest, personal history... 
Despite all the "recommendations" from the top, in the majority of locations it was precisely our coordinator comrades, carriers of the narodnaia idea of the Regiment, and not imitators of the form, who were at the center of public attention.

They went on to acknowledge that the existence of the quasi-official "clone" movement alongside the grassroots one was now a fact of life, and to call for solidarity in developing strategies for remaining true to the movement's original goals and spirit in this new context:

Today, de facto, the Regiment unavoidably exists in two versions: narodnoi and quasi-official [polukazennoi]. That means that we need to learn to cooperate with all sensible people, and not only to be on the back foot. Can one cooperate with someone who became a coordinator by appointment? If so, then how should this be done? You won't find the answer to this question in a book. The regiment began as an initiative by individuals, but today this is already narodnaia stikhiia whose life is governed by its own laws. That is, we'll have to cooperate, but let's work out the measure and depth of the compromises together, colleagues! (ibid.) $)^{11}$

This quote exemplifies how difficult it is to draw a neat line between state and civil society in Putin's Russia (on which see Hemment 2012), but also how resilient, determined, and creative this Russian civil society organization is in the face of immense state pressure. It is still an open question what kind of organization will ultimately emerge here.

\section{Crafting a New Genealogy for the BPR}

The emergence of the "clone" movement was accompanied by the creation and dissemination of a new genealogy for the movement. I turn now to examine this genealogy with the aim of identifying and exploring the ideological meanings that are being spun around it.

The BPR leaders trace the movement's beginnings to a vision that appeared in a dream to the chairman of a police battalion veterans' council in Tiumen', an “ordinary guy” by the name of Gennadii Ivanov. The story goes that he had a dream in 2007 in which he saw people in his city marching across the city square to the strains of the song "A Sacred War," and carrying portraits of war veterans. The dream left an "unforgettable" impression on him, and he decided to make this dream 
reality, organizing his friends to come out that year on Victory Day carrying photographs of deceased veterans ("O Dvizhenii" n.d). As Mischa Gabowitsch (2016) notes, it is the case that Gennadii Ivanov's Tiumen' initiative was (like other initiatives of its kind, based on the same idea of introducing veterans' photographs into Victory Day commemorative ceremonies) technically a precursor to the Tomsk movement, albeit one that mostly failed to spread further beyond the Tiumen' region. But for my purposes it is the BPR's narrative and the tropes it employs that are of interest here. The invocation of a vision or a dream as justification for a change in symbolic politics recalls the case of Dora Lazurkina's call to move Stalin's body out of the Lenin mausoleum in 1961 after Lenin appeared to her in a vision and requested this (Davies 1989: 259; Beliaev 2016). It is only representatives of the narod, ordinary people, and/or women, who ever have such visions, and this foundation story can thus be connected to the long Russian tradition of exploiting the concept of the narod for ideological ends (on which see Rzhevsky 1998: 7), based in part on the mystical notion that the members of the narod have privileged access to the supernatural realm.

The thrust of such claims about the Immortal Regiment's origins is often aimed at deflecting criticism of the state's appropriation and bureaucratization of the movement. Thus, Putin has emphasized that this is a movement that was "born not in offices, not in administrative structures, but in the hearts of our people" (cited in "Organizatory" 2015). The notion that the state merely "supports" the movement, scrupulously taking care not to interfere, is a common refrain. In April 2016 Putin asserted that the Immortal Regiment was an "absolutely honest, sincere project, and it must remain as such and must develop freely. And of course, it needs to be supported" ("Putin prizval podderzhat' 'Bessmertnyi polk'"2016). Sergei Shumakov, editor-in-chief of "Kul'tura" television channel, likewise asserted that, "This is an event which, although it is supported by the regime, has no relationship to the regime" (cited in "'Bessmertnyi polk' napugal zapad” 2015).

In 2016 Putin also called for support of the Immortal Regiment as a "genuinely narodnaia initiative" ("Putin prizval podderzhat' 'Bessmertnyi polk" 2016). One celebrity supporter of the BPR, the actor Vasilii Lanovoi, has also emphasized that this was a "surprising movement, invaluable, because it is not organized by the authorities but was born inside of society, and was instantaneously supported" ("Bessmertnyi polk" 2016b). In other words, this is an "organic" 
movement from below; in supporting it, the state is merely following the narod's lead. The pro-Kremlin journalist Petr Akopov enthused in an article entitled "Family Memory of the War Gives Birth to Narodnoe Unity" that "The Immortal Regiment movement which began ... in the provinces has reached Moscow, engulfing the capital in a wave of memory, love, and unification" (Akopov 2015). The imagery used here to describe the movement as an outpouring of elemental energy is a common motif in the media commentary, and can be connected back to the Soviet master plot's trope of "spontaneity," as outlined in Katerina Clark's classic work on Soviet culture (1981). In this connection it is perhaps not insignificant that the movement first began in the provinces, that is, in the heart of the real, the pure Russia, rather than in corrupt and Westernized Moscow.

Another key motif in the pro-BPR narrative is the notion that it is the ancestors themselves who have willed the Immortal Regiment into being. Thus, for example, Shumakov characterized the movement as:

a mysterious event of incredible power, to which we were all witness... This was a gigantic eruption of energy...

The dead rose up alongside the living-this is not an artistic conceit, this really happened (cited in "'Bessmertnyi polk' napugal zapad" 2015).

Quasi-mystical imagery of this kind is frequently used by the BPR's organizers and their supporters to describe the movement. One interview with BPR leader Nikolai Zemtsov in Komsomol'skaia pravda featured the subheading: "Death has Lost its Power over Russia" and the following quote from Zemtsov: "In essence, we, the descendants, have been mobilized and united by our fallen soldiers. There is some kind of mystery in this, something incomprehensible for human consciousness" (cited in Golubeva 2015b). ${ }^{12}$ Here, then, it is explicitly the actual fallen soldiers who are setting this process in motion, and this is framed as a kind of consolidation or birth of the community through this intervention from beyond the grave. In May 2016, the director of the Russian Academy of Sciences' Institute for Economic Strategies took this rhetoric a step further, when he called for Russia's war dead to be granted the right to vote in elections. This right could be exercised, he suggested, by the participants of the Immortal Regiment parade, who could vote 
on behalf of their ancestors. Such voting had the potential to become a "point of consolidation of society" (Obukhov 2016).

\section{The Immortal Regiment and the "Near Abroad”}

Attempts to mobilize Russia's war dead for symbolic and political capital also extend to the sphere of Russia's relations with the rest of postSoviet space. Petr Akopov, writing in the online pro-Kremlin media outlet Vzgliad, drew a direct causal link between the 2014 annexation of Crimea and the rise of the Immortal Regiment the following spring. He described both events as "miracles." "A year ago," Akopov wrote:

with the single Crimean gesture Putin awakened the Russian spirit—not because the president is some kind of superman, but because the Russian narod was acting through him-and now [with the Immortal Regiment] the narod itself has shown the first results of this awakening. (Akopov 2015)

Here, then, the Immortal Regiment effectively legitimizes the Crimean annexation. Putin is cast as a mere vehicle for the spirit and desire of the narod; and the remembrance and honoring of ancestors enacted by the Immortal Regiment is proclaimed as the "source of the power of our narod and our state" (ibid.).

Another version of the genealogy of the movement locates its genesis in the post-Soviet-Russian diaspora. Viktor Marakhovskii, the editor-inchief of Odnako, proclaimed that:

What is most interesting of all is that Victory Day's second life did not begin in Russia. It began in the "Soviet diaspora," in the newly formed independent republics... It was precisely there ... that it turned from a "holiday with tears in its eyes" to a holiday about the present day. For it became a day ... for demonstrating civilizational identity, a "Russian [russkim] holiday"-from Tallinn to Sevastopol. (Marakhovskii 2016)

Again, here, we see a shift in the emotional register, and a transformation of trauma into triumph: Victory Day used to be a mournful day, a "holiday with tears in its eyes" (a quote from the famous Brezhnev-era song Victory Day). But now, with this new ritual, it has become a holiday about today, a day for joyously displaying one's allegiance to Moscow 
across the former Soviet space. In this way, the Immortal Regiment is linked to the notion of the so-called "Russian Spring," one of the root metaphors used in the Russian media coverage of the events in Ukraine in 2014 and heralding the "awakening" of Russians oppressed throughout post-Soviet space. Consider, for example, this extract from a transcript of the live federal TV coverage of the Immortal Regiment procession on Rossiia TV channel in May 2015, hosted by patriotic talkshow host Vladimir Solov'ev and leading cinema industry figure Nikita Mikhalkov. At one point Solov'ev exclaimed, "It's marvelous-the people has awoken! ... This is the re-unification of the victor-people!" Mikhalkov responded, "This is only natural... A little girl who already lives in a completely different country, she apprehends this unity genetically ... and it will be hard to turn her, to zombify her, so to speak, although there are people who very much want to do this, as is happening with our friends and colleagues in Ukraine, you understand?" (Rossiia 2015).

As these examples show, this metaphor is inherently connected to the notion of a reawakening of the memory of the war. Indeed, the recovery of this memory is the central "trigger" enabling this awakening, often said to be willed by the ancestors, acting through the living via mysterious mechanisms. For journalist Anastasiia Skogoreva, for example, the Immortal Regiment showed that "you can write as many mendacious history textbooks and no less mendacious pseudo-academic studies as you like, but there is such a thing as genetic memory. It will awaken, and it will show us the way" (Skogoreva 2015).

\section{A Message to the World: Russia's War Dead as a Tool of Soft Power}

The BPR also prides itself on being an international movement. In 2015 Immortal Regiment processions took place in 15 different countries (Slesarchuk 2016), and in 2016, they were held in forty countries, including, for the first time, in Australia and China (Vasil'chenko 2016). The BPR organizers describe the movement's portal polkrf. $\mathrm{ru}$ as unique in its capacity to "bring together into a single space of Memory all heirs of the soldiers of the Great Patriotic War, dispersed around the world" ("Bessmertnyi polk" 2016b). The organizers have ambitions for a further exponential growth in the movement, with the 
ultimate aim of uniting the "300 million descendants of participants in the Great Patriotic War" ("Portal" 2016). The movement appears to have been integrated into the broader government campaign aimed at co-opting "compatriots" as allies in the struggle to "preserve historical memory" and counter alternative narratives of the war (see for example "Matvienko" 2016).

This performance of memory is thus also directed outwards, to an external audience. According to Mikhail Zygar', the organizers of the opening ceremony for the Sochi 2014 Olympic Games initially planned to incorporate a version of the Immortal Regiment tradition into the opening ceremony. This was planned as the climax of the ceremony, in fact. An envelope containing a photograph of a Soviet citizen who died in the war was to be placed on every seat in the stadium, and at the culmination of the ceremony, the crowd was to fall silent, and every member of the audience was to hold up their photograph above their head. The International Olympic Committee eventually vetoed this plan on the grounds that it would introduce a political dimension to the ceremony (Zygar' 2016: 320). But the story reflects an important impulse at work here: to perform this memory and kinship on the global stage, here by physically holding up photographs of the faces of the Soviet Union's war dead and subjecting the world's conscience to their steady gaze.

In an interview with the tabloid Komsomol'skaia pravda BPR leader Nikolai Zemtsov defined the message being sent to the world through the Immortal Regiment procession. He said:

[the Immortal Regiment is] a kind of translation of energies, emanating from Russia and addressed to the whole world. A reminder to Europe... "Look at the faces of the soldiers who gave you peace"... This is one of the reasons why the Immortal Regiment procession was not shown in the West. (Golubeva 2015b).

The claim that Western media refused to cover the event was made frequently; for example, Sergei Shumakov was quoted as saying that “The 'Immortal Regiment' amazed foreign journalists with its mysterious power, and ultimately it frightened them. Precisely this is why all the Western TV channels showed the Victory Parade, but ignored the mass procession of Muscovites" (“'Bessmertnyi polk' napugal zapad” 2015).

In general the BPR movement is often viewed as a potential means of projecting Russian soft power abroad by instrumentalizing Russia's war 
dead. Its international significance has been noted by Foreign Minister Sergei Lavrov, who has held up the Immortal Regiment campaign as an example of how the important work of cooperating with compatriots abroad can be carried out ("Vystuplenie" 2016). It provides a useful tool for the process described by Russian Baltic diaspora activist and wouldbe leader of the Immortal Regiment in Estonia Dmitrii Linter as "teaching the world to interpret our victories in a manner profitable for us" ("Dmitrii Linter" 2014).

\section{The Myth of Western Victory Denial}

The Immortal Regiment movement at least in part draws its energy from a hostile myth that has becoming increasingly entrenched in Russian public space over the past decade or so: the notion that the West has systematically denied the Soviet role in defeating Nazi Germany (see for example Putin's 2015 speech to the Russian "Victory" Organizational Committee session in March 2015) ("Zasedanie" 2015). Often this is combined with claims that a wholescale whitewashing and rehabilitation of the history of fascism is also underway in Western countries, and that the West is also covertly sponsoring the same process throughout postSoviet space (see for example Bordovaia 2015). Media reports of people being persecuted for trying to celebrate Victory Day and/or hold Immortal Regiment parades outside of Russia serve to reinforce this myth (see for example Neroznikova 2016; "Vystuplenie" 2016).

In turn, the Immortal Regiment is also being inserted into the narrative of Putin's Russia as leading the world's "anti-fascist" forces. For commentator Rostislav Ishchenko, “The 'Immortal Regiment' takes the last trump card away from Western propagandists-their attempt to present the Great Victory as a purely Russian national entertainment. It gathers under its banners an anti-fascist international" (Ishchenko 2015). Deputy head of the war veterans' organization Boevoe bratstvo Gennadii Shorokhov likewise commented that the Immortal Regiment represented:

not only love of ancestors, but also the active position of Russians in defending the truth about the war. The truth about the fact that the USSR and the Red Army won the war. The parades took place in the EU, in the US, not only in Russia. This testifies to the fact that we have support, that our compatriots are united with us, this is a unified Russian space... 
Let the whole world know: Russians big and small have gathered and will gather together to defend their Victory. (cited in Samoilov 2015)

One reason why this myth is so powerful is that it contains a grain of truth. Since the beginning of the war in Ukraine in particular, there have been instances of inaccurate and inflammatory high-level statements on the subject of the Soviet role in the war, such as Polish Foreign Minister Grzegorz Schetyna's statement in January 2015 that Auschwitz was liberated by Ukrainians rather than Russians, or Ukrainian Prime Minister Arsenii Yatseniuk's statement the same month on "the Soviet invasion of Ukraine and Germany" (this last was perhaps misrepresented in the pro-Kremlin media, where it was used as part of the campaign to brand Yatseniuk as a neo-Nazi) (see Izvestiia 2015). Perhaps more importantly, it is the case that popular levels of consciousness of the Soviet role in the war are generally low throughout the Western world. Surveys taken among young people in the USA have routinely shown low awareness of the fact that the USA and USSR were Allies during World War II. For the most part, however, lack of popular knowledge in the West when it comes to the Soviet role in World War II is overwhelmingly a matter of simple ignorance of basic historical facts at the broader level, and claims that this ignorance is the result of a deliberate policy of suppressing or denying historical facts are deeply misleading.

Nevertheless, the myth of Western denial of the Soviet Victory has now become so entrenched in Russian public life that it qualifies as an example of what Stuart J. Kaufman calls a "myth-symbol complex" (Kaufman 2001: 16). As such, it has strong mobilizational power, precisely because of the strength of the family memory of the immense wartime sufferings in Russia and elsewhere in post-Soviet space. ${ }^{13}$ This myth is frequently couched in the language of national humiliation. Memory functions here as a site of existential threat; and as a sacred and pure object demanding protection at all costs, up to and including the use of armed force.

\section{The "Real” Civil Society}

The sheer numbers of people taking part in the Immortal Regiment processions make this event ideal material for supporting claims about the popularity of the Putin regime. Contrasts are frequently drawn to the size of oppositional rallies, with a view to demonstrating that the 
Immortal Regiment constitutes the face of the real Russian civil society, sometimes said to be only now awakening in Russia. An article on the Russian Spring website, for example, commented that the Immortal Regiment was "probably the largest ever procession in the history of Russia ... This is the main outcome of the awakening of a genuine civil society in Russia" (Rakhmetov 2015) (original emphasis-JF).

In a similar vein, it was asserted that:

Now [after the success of the Immortal Regiment] it will be very hard for non-systemic liberals to talk about the "successes" of the protest rallies of the past year. Because all their "tens of thousands of protesters" pale in comparison to the human torrent of the "Immortal Regiment"... The columns of the "Immortal Regiment" have already been called a genuine march of millions and a genuine march of dignity. And this is right. (Samoilov 2015)

The issue of authenticity is key here, with the Immortal Regiment contrasted to the notion of color revolutions as manufactured and sponsored by foreigners. Given the periodic scandals for example during the 2011-2012 oppositional protests over crowds bused in and paid to take part in pro-regime demonstrations, the Immortal Regiment's credentials as a genuine movement from below make it especially valuable here. Samoilov's use of the term "dignity" is also an allusion to the Ukrainian "Revolution of Dignity" on the Maidan. A celebrity member of the BPR, the actor Mikhail Nozhkin, drew an explicit connection to the Maidan, commenting that the Immortal Regiment had shown "that this is an awakening that is essential for unification of the narod. There hasn't been such an upsurge of the narodnyi spirit for a long time. In essence, the 'Immortal Regiment' is in fact an 'anti-Maidan'" (cited Vinokurov 2015).

The very sight of such huge crowds of people marching through public space in Putin's Russia is itself striking, particularly in the context of how much smaller groups of oppositionists, and indeed lone individual protesters, attempting to exercise their constitutional right to peaceful public assembly have been treated by the authorities (on which see Amnesty International 2014: 6-7). This context is reflected in the curious incident in May 2015 when United Nations Secretary-General Ban Ki-Moon, in Moscow for the Victory Day celebrations and witnessing the Immortal Regiment parade, reportedly initially assumed that the 
parade was an oppositional rally. According to some media reports, he later apologized for jumping to this conclusion and commented that the Immortal Regiment was proof that Putin had "earned the love of his people" ("Ban Ki-Moon" 2015). Whether or not he really said this, it is certainly the case that the pro-Kremlin camp has sought to present this event as the irrefutable evidence of its overwhelming popularity and to insist that this is effectively a rally of people displaying and performing their loyalty to the Putin regime. For prominent political scientist and government adviser Sergei Markov, for example, the Immortal Regiment was an expression of the "huge level of support for Putin" in response to Western sanctions and to "the fact that Russians feel that the external world is waging hybrid war [against them]. And in this situation they ... support Putin and the symbol of this consolidation is the "Immortal Regiment"' (cited Klinch 2015).

Meanwhile, critics of the Immortal Regiment, and oppositionists more broadly, were labeled "hereditary Nazis" who were moved by the genetic memory of wartime treachery. This trope was activated especially after a scandal in May 2015 caused by the reported discovery of a pile of Immortal Regiment placards that had apparently been dumped after the parade was over, prompting speculation that some participants may have been paid to take part (see "V sotssetiakh" 2015). "I'm starting to conclude," wrote one journalist in connection to the critical media coverage of this incident, "that [those who criticize the Immortal Regiment] simply don't have anyone via whom they might join the 'Immortal Regiment.' Perhaps their kinfolk carried out the role of polizei and traitors in the faraway forties? Genetic memory, you know, is a strong thing" (Ryzhevskii 2015). Aleksandr Samoilov wrote in a similar vein that,

There's also one more theory on why there were no current leaders of the opposition in the "Immortal Regiment" column. This might be "hereditary." Well, their ancestors didn't fight but were also engaged in all kinds of "alternative things" in the war years. And somehow it's a bit uncomfortable to remember this (Samoilov 2015).

This notion of "hereditary Nazis" and "hereditary enemies" has been a recurring motif in pro-Kremlin media. In May 2016, for example, Komsomol'skaia pravda ran a ludicrous story on a "grandson of a Nazi attacking a granddaughter of a hero" in Kyiv on Victory Day (Kots 2016). Literaturnaia gazeta's editor-in-chief Yurii Poliakov has claimed that anti-Russian policies in Poland and Ukraine today are being promoted by "Pilsudski's grandchildren" and the descendants of Banderites 
(cited in Kuz'mina 2015). This rhetoric gains credence partly through the history of Soviet propaganda on Western governments as the heirs to Nazism (on which see Hirszowicz 1993), from which the key images and tropes are borrowed, adapted, and also applied to critics of the Putin regime more broadly, stigmatizing them as descendants of Nazi collaborators.

\section{Fusing the State and the Narod: Family Photographs in Private and in Public}

The Immortal Regiment has been hailed as representing a fusion of family memory and state memory, of the narod and the state. To quote Akopov again, in this ritual "[p] eople came together [splotilis'] around that which is the source of power of our narod and its state: around the memory of ancestors, love and respect for their fate and life" (Akopov 2015). Putin's 2016 Victory Day address also highlighted the two, intersecting dimensions of the holiday as a day on which the "sacred kinship" of the Russian state and people is affirmed: "The 9th of May is both a state holiday, and a very personal family history. It has become a symbol of the sacred kinship [sviashchennogo rodstva] of Russia and her narod... We are united by deep, penetrating emotions for our fathers, grandfathers, great-grandfathers" ("Vladimir Putin" 2016).] Again, Putin's personal participation in the procession in the capacity of an ordinary soldier's son further underlined this fusion of the top and bottom dimensions of Russian war memory. Media commentary emphasized the fact that, "[f]or the president, as for the absolute majority of Russians, the Great Patriotic War is a part of family history" ("Putin proshel po Moskve" 2015).

Yet as we have seen, it is precisely this aspect of the Immortal Regiment-its engagement with family experiences of the war-that is viewed as threatening by some patriotic commentators. Neo-Stalinist Nikolai Starikov has argued that this emphasis on the private, family dimension of memory is dangerous since it will lead to a fragmentation of national consciousness: "Instead of celebrating this day as a holiday of shared unification and Victory, it becomes broken up into millions of private 'mournings' [skorbei]" (Starikov 2015b). Indeed, as historian Nikita Sokolov has pointed out family memories of the war are often diametrically opposed to the official state memory of the war, in that the 
memories that leave their traces in the family "are precisely the horrors of war ... not the ... generalissimus and Victory" (cited Pavlova and Baryshnikov 2016). Moreover, the fact that huge numbers of the soldiers depicted in these family photographs are still missing and unaccounted for, potentially raises the uncomfortable issue of the state's failure to fulfill its duty to its war dead. ${ }^{14}$

Nevertheless, in many other respects these family photographs make an ideal tool for top-down national/state memory projects, offering a powerful way to connect together different levels and dimensions of historical narratives and experiences. Photography's much-analyzed peculiar ability to convey the illusion of direct access to an accurate and true representation of reality lends photographs a special status as historical documents and evidence, as "real" traces of the past. ${ }^{15}$ This is compounded in the case of family photographs in particular by "their embeddedness in the fundamental rites of family life" (Hirsch 1997: 5). The particular properties of photographic images mean that they cross the line between the public and the private with particular ease (Shevchenko 2014: 4), and represent a point "where private and community memory meet" (Boros 2010: 89). Family photographs thus provide a means of authenticating and authorizing particular narratives; they make it possible to humanize and create a direct point of identification with grand narratives of the nation's past, activating the imagination and emotions by showing how these narratives are reflected in the life course of an individual.

Most studies of the use of family photographs in post-Soviet Russia have focused on the Memorial Society's use of such photographs in order to provide access to suppressed dimensions of the Soviet experience, so as "to countervail the gloss of official state history" (Sarkisova and Shevchenko 2014: 151); but family photographs also offer themselves as tools for processes working in the opposite direction as we see here, where the state is attempting to use the power of these images in order to bolster and authenticate the official narrative of the past. The state authorities have engaged with these photographs directly through this movement; in Moscow, for example, it is possible to take your family photograph to various municipal offices and to have it blown up, fit to a standard format, and laminated, free of charge. ${ }^{16}$ The use of these photographs offers a way to fill the gap left by the passing of the generation of World War II veterans, who were previously a central focus of Victory Day commemorative ceremonies. ${ }^{17}$ Indeed, the transition from living veterans to their photographic images opens up new possibilities 


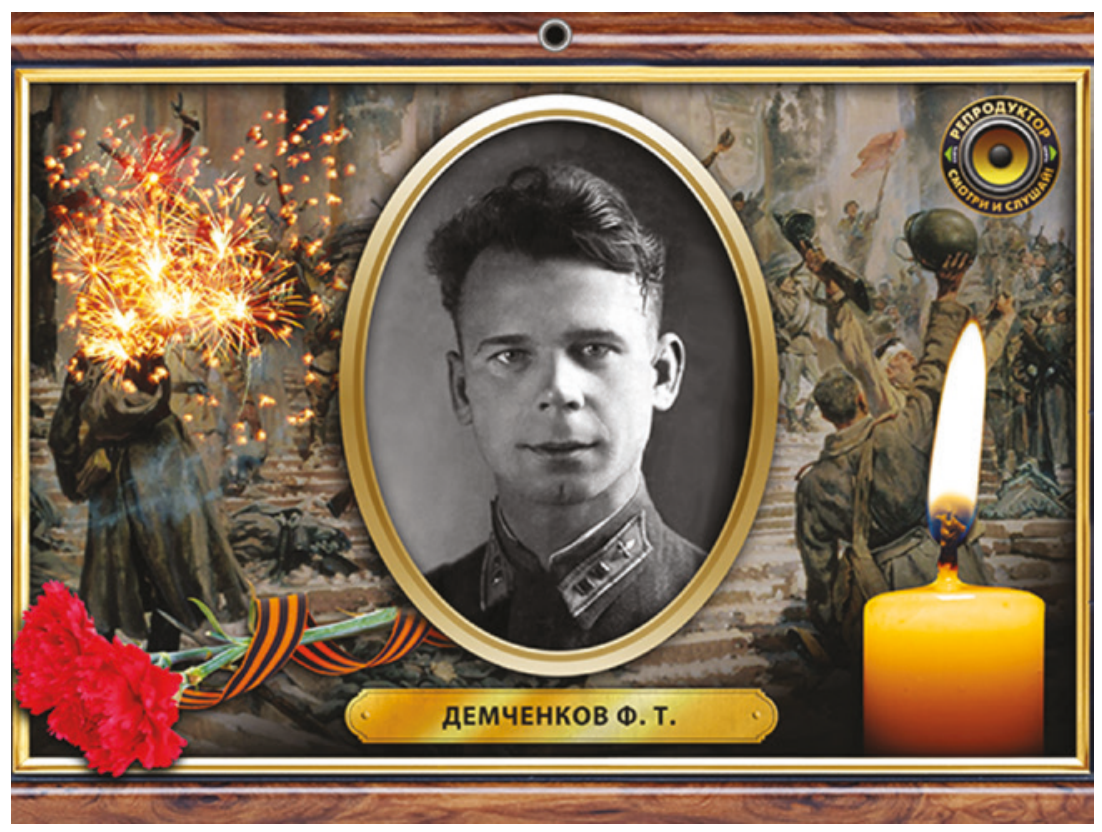

Fig. 11.1 The 3D "Living Memory" Talking Portrait. Source Valentin Slesarchuk, 'U "Bessmertnogo polka" poiavilsia novyi format', Utro.ru, 25 February 2016, http://www.utro.ru/articles/2016/02/25/1272351.shtml

for instrumentalization of the war memory. The silent form of witnessing to the past enacted by these photographs enables a kind of ventriloquizing - the eyes seem to speak eloquently, the words and meaning can be supplied by the state at will.

Animated version with sound available at: http://www.memory.live.

Figure 11.1 shows an especially striking example of how these two dimensions-private family memory and public official memory-are being fused together in this new tradition, and also commercialized. The image shows the 3D "Living Memory" interactive portrait, a multimedia product that was launched in 2016 in Krasnoiarsk. It features animated elements, such as a candle flame that flickers in response to passers-by, and interactive audio components-one can record and play back one's own "radio show" about the soldier, for example. The product is designed specifically for use both as a family shrine to hang 
on the wall at home for most of the year, and also for public display in the annual Immortal Regiment procession. According to its website, it is now producing samples for use in educational and other state institutions, apparently on commission from the Russian Ministry of Education and Science. ${ }^{18}$ While the commercial success of this product is unclear, the example is suggestive of the ways in which people are being encouraged to use these photographs in the public and the private realms interchangeably. One journalist wrote of the Immortal Regiment, "Who could have thought ... that this simple step-printing out a photograph and coming out onto the street with it-would warm the hearts and souls of millions across the whole country?" (Golubeva 2015a). This quote pinpoints an important element of this new tradition: the fact that it involves taking these photographs out of the private family domestic setting or domain, and transferring them into public space. This then renders them potentially available as cultural, ideological, and political resources, including for the state.

\section{A Celebration of Vitality}

Kul'tura television channel executive Sergei Shumakov has called the Immortal Regiment movement "the breathing of soil and fate," and has claimed that it has "returned soil and fate to us" (cited in "Bessmertnyi polk' napugal zapad" 2015). This imagery can be linked back to various strands of the Russian nationalist tradition such as pochvennichestvo or the Village Prose movement. The pro-Kremlin language of war memory today is one that is also saturated with blood and soil, and with biological metaphors. In the remainder of the chapter I examine some of these key tropes.

First, there is a strong preoccupation here with what we might characterize under the umbrella term of "vitality." The Immortal Regiment is frequently said to have revitalized the Russian war memory, and made it young again. As Marakhovskii put it: "The 'Immortal Regiment' has given Victory Day a second life ... without any grey hair and without any nostalgia" (Marakhovskii 2016). This is a new incarnation of Victory, and a new incarnation of Russia, an awakening of new life. For Vladimir Mamontov, head of Govorit Moskva radio, the May 2015 Victory Day celebrations had made him realize that "I was mistaken when I wondered whether our Victory had grown old... She is young, full of power" ("Vopros dnia" 2015). 
Both official and popular forms of Russian war commemorative paraphernalia are characterized by a striking prevalence of imagery featuring children and babies - both today's living children, and children as yet unborn. ${ }^{19}$ The pervasiveness of images of infants and children dressed in Great Patriotic War Soviet military uniform was particularly noticeable during the 2015 and 2016 Victory Day commemorations, ${ }^{20}$ and especially in Crimea. Mothers paraded in uniform together with their young children in prams in Simferopol' on Victory Day 2015 (Oblomov 2015); and to mark the Day of Defender of the Fatherland (23 February) in Crimea in 2016 a group of mothers took part in a ceremony in which their new-born baby boys were issued their call-up papers in advance ("V Krymu" 2016). We might read this trope as another instance of the way in which trauma is being transmuted back into triumph, and mourning into aggression, but an aggression that is righteous, "pure," and innocent, and hence embodied in the symbol of the child or infant warrior.

This preoccupation is also a characteristic of Russian official discourse more broadly. Consider for example the recent spate of laws related to children's issues, in which putative concerns over the safety and wellbeing of Russian children have been used as a pretext for politically motivated legislation, as in the case of the 2012 Dima Yakovlev law which banned US citizens from adopting Russian children in response to the Magnitsky bill. The need to protect children has been held up as justification for internet censorship and for the 2013 anti-gay propaganda law, and pro-Kremlin organizations such as "Russkie materi" (created 2011) campaign to raise awareness of what they view as the repressive practices of Western state social services and rescue Russian children subjected to these abroad. ${ }^{21}$ In 2016, Putin's "Direct Line" conversation with the nation was noteworthy for the prominence of children among the participants (and much mocked on social media for this).

The flipside of this trope is the notion of the "degeneracy" of the West, standing in stark contrast to the vitality and purity of the "Russian world." This degeneracy and corruption is connected to Western Europe's distorted memory of World War II. Thus for example, the head of the Night Wolves bikers "The Surgeon," one of the high-profile celebrity participants of the Immortal Regiment parade, commented that the 2015 Victory Day celebrations were not just a triumph for Russia but were also about "testing Europe for lice" ("Vopros dnia" 2015). Even more radically dehumanizing imagery of this kind is reserved for 
pro-Maidan Ukrainians; not only do they lack "vitality," but they are strikingly often cast as the living dead, whether in the form of visual memes circulating online in which Maidan activists are styled as zombies (as in "Ukrainski zombilend" 2014), or in texts such as Roman Nosikov's diatribe against Ukrainian nationalism:

The truth is that so-called "Ukrainian nationalism" is nothing but decaying flesh which has already proved that it has no place in the land of the living, but which is still able to walk, kill, and sing hymns to death and decomposition. And the truth is also that envy of life, nobility, and victory prevents this zombie even from dying in a dignified way-it's capable only of carking it in the midst of lies and paroxysms of hatred. (Nosikov 2015)

Again, strikingly often, such imagery contains the notion that it is the wrong kind of memory of the war, or a lack of memory of the war, that is to blame for this state of affairs-note, for example, in the passage above, the reference to the Ukrainian "envy of victory." Likewise, it is precisely through an attack on the Russian memory of Victory that enemies seek to destroy Russia. For Nikolai Starikov, the ultimate aim being pursued by Russia's enemies in Ukraine is "to bury the memory of Russia's victories and to solve the 'Russian' question definitively. Simply to annihilate us [Prosto chtoby nas ne bylo.]” (Starikov 2014: 7).

Meanwhile, the Victory itself is cast as confirmation and the result of the Russian people's innate vitality (or passionarnost', to borrow the popular term coined by Lev Gumilev). In 2016, Putin described the Victory as evidence of the "genuine life force of our narod" ("Vladimir Putin" 2016). In turn, the memory of the Victory serves as the source of kind of esoteric power, as in Sergei Markov's claims that: "We draw power from this Great Victory... We take these photographs, so as to take possession of the power of these photographs for ourselves" (cited in "Osoboe mnenie" 2016). For Markov, this power is needed in order to defend Russia from dismemberment and annihilation. He sees the rise of the Immortal Regiment as the Russian people's response to events in Ukraine:

[W]hy did [the Immortal Regiment] become so popular only after the coup in Ukraine? Because this is a war, everyone understands this very well... [T] he Immortal Regiment is our reaction to this war [being waged 
by the West] against Russia... [T] he Immortal Regiment... is a great ascension of the narod with the aim of defending its country. (ibid.)

\section{Conclusion}

[We] have a new war now. A new narod is taking shape in our country. We must win this war!... You know, the Immortal Regiment - essentially this is the new Russian [rossiiskii] narod. The new rossiiskii narod.

Sergei Markov. (cited in "Osoboe mnenie" 2016)

This chapter has outlined the contours of the official and patriotic discourse surrounding the war memory in Russia as it has been taking shape since the beginning of the war in Ukraine and expressed through the pro-Kremlin commentary on the Immortal Regiment movement. As this quote from Sergei Markov illustrates, the Immortal Regiment movement is being claimed first and foremost as marking the emergence of something new: a new stage in the development of the Russian nation-the genesis of a new form of that nation, even. While the Immortal Regiment ritual is focused on remembering a past war, for the pro-Kremlin camp, its significance has everything to do with present and future wars. The nature of these wars is often left undefined, but it is clear that they may be both international and internal in scope, and that domestic enemies are among those who will have to be defeated in these conflicts.

As we have seen, this latest incarnation of Russian war memory is a high-octane discourse, built on hostile myths that depict Russian memory and identity as radically under threat, and that potentially justify and fuel inter-ethnic violence. Within this discourse, memory of the war takes on a life of its own - if taken to its logical conclusion, then citizens are transformed into mere vehicles of an immutable genetic memory which has value in its own right and which must be reproduced at all costs. This is a discourse that has already been used to justify military aggression in Ukraine, and that is being used most fundamentally as a tool for bolstering the current regime's legitimacy. At the most basic level this war memory is being framed literally as a matter of life and death-of "vitality" twinned with and fueled by the willingness to shed blood in the name of that vitality. 


\section{Notes}

1. The Immortal Regiment movement has sparked a counter-action, the "Immortal Barracks," aimed at shifting the focus onto the memory of victims of state terror; see further http://bessmertnybarak.ru.

2. Historian Ivan Kurilla is one of those who take a more optimistic view of the Immortal Regiment phenomenon (see Reut 2016). For a discussion of the movement's transformative potential, see Gabowitsch (2016).

3. Thus, paradoxical statements like the following become possible: "Russian [russkaia] national pride is in general a unique thing, because it's international. There's no way it can be compared with Nazism, because in our country Russians and Ukrainians fought in the same ranks" (Bukker 2015). For reflections on the instrumentalization of the figure of the Red Army soldier in connection with Soviet war graves in Poland, see Nowak (2013); and on the construction of the "Soviet fighting family," from which certain groups were excluded, see Weiner (2012).

4. The fact that the parade was granted permission to march across Red Square was significant here. The territory of Red Square is a special category of public space that comes under the direct auspices of the president, and the fact that Putin had personally granted permission to march across the Square was emphasized by the BPR leaders (“Obshchestvennaia organizatsiia” 2016).

5. burckina_faso is not one of the top bloggers, but has a respectable rating position on Livejournal: 427 overall and 18 for Volga region (as at 17 December 2016); http://burckina-faso.livejournal.com/profile.

6. "Immortal Regiment-Moscow" (parad-msk.ru) is also part of "Immortal Regiment of Russia." The story of its leader Nikolai Zemtsov's relations with the original civic movement is complicated and tortuous; one side of the story is told at moypolk.ru.

7. It should be noted that as Mischa Gabowitsch (2016) has pointed out, the grassroots movement has also cooperated in various ways with local state authorities and other powerful institutions such as Gazprom from the outset, and so the state-society divide should not be overstated; but the organizers have attempted to set limits on such cooperation.

8. Later, United Russia member Viacheslav Makarov would claim that the party had been involved in creating the movement; "We have given immortal life to the heroes of the war," he said ("Spiker" 2016). The Russian Ministry of Culture also claimed credit for organizing the Immortal Regiment processions in its 2014 report (Ministerstvo Kul'tury RF 2015: 13). 
9. This is according to Lapenkov, cited Galeeva (2015). See also the comment by the leader of the "Search Movement of Russia" Yelena Tsunaeva that the development of the BPR (presumably, she meant its growth and its increasingly close relationship to the state) was similar to that of the search movement; that the founders must understand that the initiative needs "to develop," and that if they did not wish to undertake such development then they should leave this to others; cited Vinokurov (2015). On the poiskoviki, see Chapter 14.

10. They have invited and crowdsourced reports of such violations, which are gathered at http://www.moypolk.ru/gauptvahta.

11. They also proposed the radical solution of dissolving all existing structures, including their own, before convening a "legitimate congress of the real coordinators" (ibid.).

12. As various commentators pointed out in social media, this dimension of the Immortal Regiment uncannily recalls nineteenth-century philosopher Nikolai Fedorov's project aimed at resurrecting the dead.

13. According to a 2015 survey, $52 \%$ of Russians report that a close relative perished during the Great Patriotic War; 20 percent say a close relative went missing; $22 \%$ do not know or unable to say whether any family members were killed in the war; Levinson (2015).

14. Some estimates place the number of Russian soldiers still missing and unaccounted for at around five million; see further the website of the Forgotten Regiment project, which is aimed at identifying and documenting Russian soldiers missing from this and other wars: http://www.polk. ru/vojjna-v-chechne/. The Putin government has taken a series of measures aimed at rectifying this situation and particularly focused on locating the families of soldiers who never received their decorations; see for example: http://podvignaroda.mil.ru/.

15. The classic texts here are Sontag (1977) and Barthes (1981).

16. See parad-msk.ru for details on the free service offered by all Moscow municipal state service centers for printing out portraits for use in the Immortal Regiment procession.

17. As Sarkisova and Shevchenko point out, family photographs "reside at the intersection between cultural and communicative memory" (2014: 151). On this distinction see further the Introduction to this volume.

18. http://memory.live/ (accessed 17 December 2016).

19. See for example Odessan child singer Anna Komiakova's performance of the song "Aist na kryshe," available at: https://www.youtube.com/ watch?v=emThQlfdEBk. While the song's lyrics celebrate peace, this is a peace that is only enabled by the military hardware over which children 
clamber in the background in the course of the video, perhaps reflecting the ways in which this kind of militarism arises out of a fundamental desire for security, sought in a powerful state capable of threatening potential enemies and enabling its population to live out the fantasy of a childlike and innocent existence. Cf. the "pervasiveness of the theme of infants" in French World War I patriotic culture; Huss (2004). See also Chap. 9. On biological national discourses in contemporary Russia, see also Hemment (2012: 249-250).

20. See for example a Blagoveshchensk billboard featuring an infant, wearing nothing but a pilotka, with the slogan: "I'm going to be a hero too, like my great-grandpa"; image available at: http://antikor.com.ua/ articles/102370-ljapy_ko_dnju_pobedy_spasibo_bebu_za_podebu/print. 21. See the movement's official website: http://www.russianmothers.ru/.

\section{REFERENCES}

Akopov, P. 2015. "Semeinaia pamiat' o voine rozhdaet narodnoe yedinstvo." Vzgliad, 12 May. Retrieved 7 June 2016 from http://vz.ru/politics $/ 2015 / 5 / 12 / 744873 . h t m l$.

Amnesty International. 2014. Violation of the Right to Freedom of Expression, Association and Assembly in Russia, Oct. Retrieved 20 Aug 2016 from https://www.amnesty.org/download/Documents/8000/eur460482014en. pdf.

Assmann, J. 2011. Cultural Memory and Early Civilization: Writing, Remembrance and Political Imagination. Cambridge: Cambridge University Press.

Babchenko, A. 2016. “'Bessmertnyi polk': massovyi kul't smerti-izbytochen.” Politolog.net, 10 May. Retrieved 11 May 2016.

"Ban Ki-moon". 2015. "Ban Ki-Moon: Putin has Won the Love of his People." laInfo.es, 9 May. Retrieved 7 June 2016 from http://lainfo.es/ en/2015/05/09/ban-ki-moon-putin-has-won-the-love-of-his-people/.

Barthes, R. 1981. Camera Lucida. New York: Hill \& Wang.

Beliaev, I. 2016. "Vnuchka Nikolai II." Radio Svoboda, 10 May. Retrieved 7 June 2016 from http://www.svoboda.org/content/article/27725608.html.

Bessel, R. 2010. "Violence and Victimhood: Looking Back at the World Wars in Europe." In Experience and Memory: The Second World War in Europe, eds. J. Echternkamp and S. Martens, 229-269. New York and Oxford: Berghahn Books.

Bessmertnyi barak. n.d. http://bessmertnybarak.ru/. 
“'Bessmertnyi polk' napugal zapad”. 2015. Dni.ru, 22 July. Retrieved on 7 June 2016 from http://www.dni.ru/society/2015/7/22/309980.html.

"Bessmertnyi polk." 2016a. "Bessmertnyi polk. Itogi i budushchee," May. Retrieved 14 July 2017 from http://www.moypolk.ru/bessmertnyypolk-itogi-i-budushchee.

"Bessmertnyi polk." 2016b. "Bessmertnyi polk stanovitsia global'noi sotsial'noi set'iu." Bessmertnyi polk Rossii website, 6 April. Retrieved 9 June 2016 from https://polkrf.ru/news/300/bessmertnyiy_polk_stanovitsya_globalnoy_ sotsialnoy_setyu.

Bordovaia, I. 2015. "Dlia vragov—oprichniki, dlia druzei-geroi." Vecherniaia Moskva, 73, 24 April.

Boros, G. 2010. "Buried Images: Photography in the Cult of Memory of the 1956 Revolution". In Exposed Memories: Family Pictures in Private and Collective Memory, eds. Z. Bán, and H. Turai, 89-112. Budapest: CEU Press.

BPR. n.d. https://polkrf.ru/about/. Retrieved 17 Aug 2017.

Buckler, J., and E.D. Johnson (eds.). 2013. Rites of Memory: Public Commemoration in Russia and Eastern Europe. Evanston and IL: Northwestern University Press.

Bukker, I. 2015. "Sovetskogo soldata gnobiat, potomu chto boiatsia." Pravda, 2 Oct. Retrieved on 16 April 2016 from http://www.pravda.ru/society/ fashion/models/02-10-2015/1276585-poisk_war-0.

burckina_faso. 2016. "Pro 'Bessmertnyi polk': ot razygryvaniia bylogo triumfa $\mathrm{k}$ pokhoronnomu obriadu." LiveJournal, 29 April. Retrieved 25 July 2016 from http://burckina-faso.livejournal.com/1560463.html.

Burke, P. 2010. "Co-memorations. Performing the Past." In Performing the Past: Memory, History, and Identity in Modern Europe, eds. K. Tilmans, F. van Vree, and J. Winter. Amsterdam: Amsterdam University Press.

Clark, K. 1981. The Soviet Novel: History as Ritual. Bloomington and Indianapolis: Indiana University Press.

Confino, A. 2005. "Remembering the Second World War, 1945-1965: Narratives of Victimhood and Genocide". Cultural Analysis 4: 46-75.

Danilova, N. 2015. The Politics of War Commemoration in the UK and Russia. New York: Palgrave Macmillan.

Davies, R.W. 1989. Soviet History in the Gorbachev Revolution. London: Macmillan.

“Den’ Rossii.” 2015. "Den' Rossii: V Tambove proshel parad detskikh voennykh koliasok." Apostrof, 13 June. Retrieved 15 May 2016 from http://apostrophe.com.ua/news/society/2015-06-13/den-rossii-v-tambove-proshel-paraddetskih-voennyih-kolyasok/26818. 
"Dmitrii Linter." 2014. "Dmitrii Linter: Nashi propagandistskie shedevry dostoiny Gollivuda." Novyi den', 17 Nov. Retrieved 7 June 2016 from http:// newdaynews.ru/propaganda/518184.html.

Erll, A., and A. Rigney. 2009. "Introduction: Cultural Memory and its Dynamics.". In Mediation, Remediation and the Dynamics of Cultural Memory, eds. A. Erll, and A. Rigney, 1-11. Berlin and New York: Walter de Gruyter.

Gabowitsch, M. 2015. "Pamiatnik i prazdnik: ethnografiia Dnia Pobedy." Neprikosnovennyi zapas 101(3). Retrieved on 16 May 2016 from http:// www.nlobooks.ru/node/6370.

Gabowitsch, M. 2016. "Are Copycats Subversive? Strategy-31, the Russian Runs, the Immortal Regiment, and the Transformative Potential of NonHierarchical Movements." Problems of Post-Communism: 1-18.

Galeeva, V. 2015. "Funktsionery khotiat povesti 'Bessmertnyi polk." fontanka. ru, 30 May. Retrieved on 16 May 2016 from http://www.fontanka. $\mathrm{ru} / 2015 / 05 / 29 / 166 /$.

Golubeva, Ye. 2015a. "Sluzhu Bessmertnomu polku." Komsomol'skaia pravda 141, 11 Dec.

Golubeva, Ye. 2015b. “'Bessmertnyi polk': My po-novomu prochli nashu Pobedu." Komsomol'skaia pravda 134, 25 Nov.

Golubeva, Ye. 2015c. "Vasilii Lanovoi: 'Bessmertnyi polk' zakladyvaet podlinnuiu osnovu grazhdanskoi solidarnosti.'” Komsomol'skaia pravda 127, 9 Nov.

Gorodskoi reporter. 2016. “'Bessmertnyi polk' obzavelsia sobstvennym koll-tsentrom." Gorodskoi reporter, 20 April. Retrieved 9 June 2016 from http://cityreporter.ru/bessmertnyj-polk-obzavelsya-sobstvennym-koll-tsentrom/.

Hemment, J. 2012. "Nashi, Youth Voluntarism, and Potemkin NGOs: Making Sense of Civil Society in Post-Soviet Russia." Slavic Review. 71: 2: 234-60.

Hirsch, M. 1997. Family Frames: Photography, Narrative, and Postmemory. Cambridge, MA, and London: Harvard University Press.

Hirszowicz, L. 1993. "The Holocaust in the Soviet Mirror". In The Holocaust in the Soviet Union: Studies and Sources on the Destruction of the Jews in the Nazi-Occupied Territories of the USSR, 1941-1945, ed. L. Dobroszycki, and J.S. Gurock, 29-59. New York and London: M. E. Sharpe.

Huss, M. 2004. "Belonging to a 'Grandiose' Family: Visual Memory and Representations of the Chain of Solidarity between the Generations in French First World War Culture". In Memory and Memorials: The Commemorative Century, eds. W. Kidd, and B. Murdoch, 41-60. Aldershot: Ashgate. 
Ishchenko, R. 2015. "Marsh v vechnost'." RIA Novosti, 14 May. Retrieved 7 June 2016 from http://ria.ru/columns/20150514/1064542585.html.

Izvestiia. 2015. "Yevropa nakhoditsia v kriticheskoi tochke." Izvestiia 2, 13 Jan.

Kaufman, S.J. 2001. Modern Hatreds: The Symbolic Politics of Ethnic War, 2001. Ithaca and London: Cornell University Press.

Klinch. 2015. "Klinch. Rossiia, god 2015: bol'she obrela ili poteriala?” Ekho Moskvy, 30 Dec. Retrieved 29 Aug 2016 from http://echo.msk.ru/ programs/klinch/1685050-echo/.

Kolstø, P. 2016. "Introduction: Russian Nationalism is Back-But Precisely What Does That Mean?". In The New Russian Nationalism: Imperialism, Ethnicity and Authoritarianism 2000-2015, eds. P. Kolstø, and H. Blakkisrud, 1-17. Edinburgh: Edinburgh University Press.

Kots, A. 2016. "Vnuki banderovtsev protiv vnukov geroev." Komsomol'skaia pravda, 11 May. Retrieved 12 May 2016 from http://www.kp.ru/ daily/26527/3544431/.

Kuz'mina, O. 2015. "Yurii Poliakov: Pobeda voshla v gennuiu pamiat' naroda." Vecherniaia Moskva 75, 28 April.

Lapenkov, S. n.d. Commentary on Statute, at Bessmertnyi polk website. Retrieved 8 June 2016 from http://moypolk.ru/ustav-polka.

“Letopis' Polka.” n.d. Retrieved 25 Aug 2016 from http://moypolk.ru/ letopis-polka.

Levinson, A. 2015. "Voina kak proshloe i kak budushchee." Neprikosnovennyi zapas 101 .

Marakhovskii, V. 2016. "Bessmertnyi polk podaril vtoruiu zhizn’ Dniu Pobedy." Blogpost, 28 April. Retrieved on 2 May 2016 from http://histrf.ru/ uchenim/blogi/post/post-3138.

"Matvienko." 2016. "Matvienko: Rossiia ne budet terpet' pritesnenii sootechestvennikov." Grani.ru, 4 June. Retrieved on 7 June 2016 from http://graniru. org/Politics/Russia/m.251966.html.

Medinskii, V. 2016. "Bez 'belykh' i 'krasnykh.'” Rossiiskaia gazeta, 29 June. Retrieved 1 July 2016 from https://rg.ru/2016/06/29/vladimir-medinskijliuboe-22-iiunia-my-dolzhny-zakanchivat-9-maia.html.

Merridale, C. 2010. Ivan's War: The Red Army 1939-1945. London: Faber and Faber.

Ministerstvo Kul'tury RF. 2015. “Gosudarstvennyi doklad o sostoianii kul'tury v Rossiiskoi Federatsii v 2014 godu." Retrieved 20 Dec 2016 from http:// mkrf.ru/upload/mkrf/mkdocs2015/\%D0\%B3\%D0\%BE\%Dl\%81\%D0\% B4\%D0\%BE\%D0\%BA\%D0\%BB\%D0\%B $\%$ D D $0 \%$ B 4_\%D0\%B2\%D0\%B5\%D $1 \% 80 \% \mathrm{D} 1 \% 81 \% \mathrm{D} 0 \% \mathrm{~B} 8 \% \mathrm{Dl} \% 8 \mathrm{~F} \% 20 \% \mathrm{D} 0 \% 93 \% \mathrm{D} 0 \% 94 \% 20 \% \mathrm{D} 0 \% \mathrm{~B} 8 \% 20$ \%D0\%Al\%D0\%A4\%20\%D0\%A4\%D0\%98\%D0\%9D\%D0\%90\%D0\%9B.pdf. 
“My budem delat' svoe delo!" 2016. Bessmertnyi polk v Latvii website. 13 April. Retrieved 9 June 2016 from http://polk.lv/component/k2/ item/13-my-budem-delat-svoe-delof.

Neroznikova, Ye. 2015. “Ob”edinenie rossiian strashno dlia tekh, kto khotel by razdroblennosti obshchestva."' Vzgliad, 12 May. Retrieved from http:// vz.ru/politics/2015/5/12/744727.html.

Neroznikova, Ye. 2016. "Nasha aktsiia razrushaet estonskii mif ob okkupatsii."” Vzgliad, 5 May. Retrieved on 7 June 2016 from http://www.vz.ru/politics/2016/5/5/808910.html.

Nordvik, V. 2015. "Sergei Lapenkov: 'Bessmertnyi polk'-absoliutno lichnaia istoriia." Rossiiskaia gazeta, 26 Aug. Retrieved on 8 Jan 2016 from: http:// www.rg.ru/2015/08/26/rodina-polk.html.

Nosikov, R. 2015. Rossiia budet voevat'. Moscow: Algoritm.

Nowak, A. 2013. "Murder in the Cemetery: Memorial Clashes over the Victims of the Soviet-Polish Wars". In Memory and Theory in Eastern Europe, eds. U. Blacker, A. Etkind, and J. Fedor, 149-171. New York: Palgrave Macmillan.

Oblomov. 2015. "ParAD marazma v NamKryshe: 'tsirk s koniami, mordoprobeg i mamki v gimnasterkakh.” Divannaia Sotnia, blogpost, 9 May. Retrieved 15 May 2016 from http://divannaya-sotnya.com.ua/Oblomov/parad-marazmav-namkryshe-cirk-s-konyami-mordoprobeg-i-mamki-v-gimnasterkah.html.

"Obshchestvennaia organizatsiia." 2016. "Obshchestvennaia organizatsiia 'Bessmertnyi polk-Moskva' nachala podgotovku $\mathrm{k}$ narodnoi chasti parade Pobedy." Bessmertnyi polk-Moskva website, 17 March. Retrieved 9 June 2016 from http://parad-msk.ru/obshhestvennaya-organizaciya-bessmertnyjpolk-moskva-nachala-podgotovku-k-narodnoj-chasti-parada-pobedy/.

Obukhov, A. 2016. "Glava institute RAN predlozhil razreshit' mertvym golosovat' na vyborakh." Moskovskii komsomolets, 20 May. Retrieved on 7 June 2016 from http://www.mk.ru/politics/2016/05/20/glava-instituta-ran-predlozhil-razreshit-mertvym-golosovat-na-vyborakh.html.

"O Dvizhenii." n.d. Bessmertnyi polk-Moskva website. Retrieved on 7 June 2016 from http://parad-msk.ru/about-us/.

“Organizatory." 2015. "Organizatory 'Bessmertnogo polka' nazvali real'noe chislo uchastnikov aktsii v Moskve." Lenta.ru. 12 May. Retrieved on 7 June 2016 from https://lenta.ru/news/2015/05/12/bessmertniypolk/.

"O situatsii." n.d. "O situatsii v Moskve. Zaiavlenie shtaba Bessmertnogo polk." Bessmertnyi polk website. Retrieved 26 July 2016 from http://moypolk. ru/o-situacii-v-moskve-zayavlenie-shtaba-bessmertnogo-polka.

"Osoboe mnenie." 2016. "Osoboe mnenie." Ekho Moskvy, 3 March. Retrieved 28 Aug 2016 from http://echo.msk.ru/programs/klinch/1685050echo/2015. 
Parkhomenko, S. 2015. Facebook post, 12 May. Retrieved on 5 June 2016 from: https://www.facebook.com/serguei.parkhomenko/posts/1020650 3332611530.

Pavlova, S. and V. Baryshnikov. 2016. "Provokatsiia pod prismotrom politsii." Radio Svoboda, 28 April. Retrieved 29 April 2016 from http://www.svoboda. mobi/a/27704522.html.

"Portal." 2016. "Portal 'Bessmertnyi polk Rossii' prizvan ob"edinit' 300 millionov potomkov uchastnikov VOV." TASS.ru, 5 April 2016, http://tass. ru/obschestvo/3177319. Retrieved on 3 June from http://nlobooks.ru/ node $/ 6369$.

Putin, V. 2012. "Poslanie Prezidenta Federal'nomu Sobraniiu." 12 Dec. Extracts available at Pravoslavie.ru. Retrieved 25 Aug 2016 from http://www.pravoslavie.ru/58087.html.

"Putin proshel po Moskve." 2015. "Putin proshel po Moskve s portretom otsa." Dni.ru. 9 May. Retrieved on 3 June 2016 from: http://www.dni.ru/ polit/2015/5/9/293191.html.

"Putin prizval podderzhat' 'Bessmertnyi polk." 2016. "Putin prizval podderzhat' 'Bessmertnyi polk' kak 'poistine narodnuiu initsiativu.'” Lenta.ru, 5 April. Retrieved 9 June 2016 from https://lenta.ru/news/2016/04/05/ putinpolk/.

Rakhmetov, I. 2015. “Bessmertnyi polk”, itogi. Samoe glavnoe.” Russkaia vesna, 12 May. Retrieved on 7 June 2016 from http://rusvesna.su/ recent_opinions/1431416833.

Reut, O. 2016. "Posleslovie k Dniu Pobedy: kuda uidet 'Bessmertnyi polk'?" Mustoi.ru, 12 May. Retrieved 7 June 2016 from http://mustoi.ru/ posleslovie-k-dnyu-pobedy-kuda-ujdet-bessmertnyj-polk/.

Rossiia. 2015. Rossiia TV Channel Live Coverage of Immortal Regiment, 9 May. Retrieved from https://www.youtube.com/watch?v=DnJPfZCuZJ0.

Ryzhevskii, P. 2015. “'Bessmertnyi polk' dlia nikh-buffonada.” Politicheskaia Rossiia, 22 May. Retrieved 2 May 2016 from http://politrussia.com/ society/ni-styda-ni-304/.

Rzhevsky, N. 1998. "Russian Cultural History: Introduction". In The Cambridge Companion to Modern Russian Culture, ed. N. Rzhevsky. Cambridge: Cambridge University Press.

"Samarskii 'Yermalash'." 2016. "Samarskii 'Yeralash' snial rolik o prizrake 10-letnego soldata." lenta.ru, 27 April. Retrieved 17 Dec 2016 from https://lenta. $\mathrm{ru} /$ news/2016/04/27/ghostofmay9/.

Samoilov, A. 2015. "Bessmertnyi polk: Kto ispugalsia nastoiashchego 'marsha millionov." Politonline.ru, 10 May. Retrieved 7 June 2016 from http:// www.politonline.ru/interpretation/22881651.html. 
Sarkisova, O. and O. Shevchenko. 2014. "Soviet Past in Domestic Photography: Events, Evidence, Erasure." In Double Exposure: Memory and Photography, eds. O. Shevchenko. New Brunswick, NJ, and London: Transaction Publishers. Shevchenko, O. 2014. "Memory and Photography: An Introduction". In Double Exposure: Memory and Photography, ed. O. Shevchenko. New Brunswick and London: Transaction Publishers.

Skogoreva, A. 2015. "Duma o triedinstve i geneticheskaia pamiat'." Politikus.ru, 10 May. Retrieved 2 May 2015 from http://politikus.ru/ articles/49917-duma-o-triedinstve-i-geneticheskaya-pamyat.html.

Slesarchuk, V. 2016. "U 'Bessmertnogo polka' poiavilsia novyi format." utro. $r u, 25$ Feb. Retrieved on 9 May 2016 from http://www.utro.ru/articles/2016/02/25/1272351.shtml.

Soltysik Monnet, A. 2012. "War and National Renewal: Civil Religion and Blood Sacrifice in American Culture." European Journal of American Studies 7(2).

Sontag, S. 1977. On Photography. New York: Farrar, Straus \& Giroux.

"Spiker." 2016. "Spiker ZakSa: 'Bessmertnyi polk' organizovala 'Yedinaia Rossiia."” Fontanka.ru, 12 July. Retrieved 26 July 2016 from www.fontanka. $\mathrm{ru} / 2016 / 07 / 12 / 132 /$.

Starikov, N. 2014. Ukraina: khaos i revolintsiia—oruzhie dollar. St Petersburg: Piter.

Starikov, N. 2015a. "Aktsiia Bessmertnyi polk i inostrannye granty." Blogpost, 22 April. Retrieved 7 June 2016 from https://nstarikov.ru/blog/50934.

Starikov, N. 2015b. "Vedet li Bessmertnyi polk k bessmertiiu Pobedy." Blogpost. 8 April. Retrieved 7 June 2016 from https://nstarikov.ru/blog/50518.

Staropopov, R. 2016. "Linter—ob organizatsii shestviia 'Bessmertnyi polk': pri chem zdes' posol'stvo RF?” rus.delfi.ee, 9 May. Retrieved 14 Dec 2016 from http://rus.delfi.ee/daily/estonia/linter-ob-organizacii-shestviya-bessmertnyjpolk-pri-chem-zdes-posolstvo-rf?id=74469429.

Thelen, D. 1998. "Afterthoughts: A Participatory Historical Culture". In The Presence of the Past: Popular Uses of History in American Life, eds. R. Rosenzweig, and D. Thelen. New York: Columbia University Press.

Thomson, A. 2013. ANZAC Memories: Living with the Legend. Clayton: Monash University Publishing.

“Ukrainski zombilend." 2014. "Ukrainski zombilend: vzgliad iznutri." Moi mir, blogpost, 23 Sep. Retrieved 25 Aug 2016 from https://my.mail.ru/community/interfront/6FBF9EF5F4BB7941.html.

"Ustav Polka." n.d. Bessmertnyi polk website. Retrieved 8 June 2016 from http://moypolk.ru/ustav-polka.

Vasil'chenko, Ye. 2016. “'Bessmertnyi polk' vyvedet na ulitsy mira bolee 10 millionov chelovek." www.mk.ru. 8 May. Retrieved 8 September 2017 
from http://www.mk.ru/social/2016/05/08/bessmertnyy-polk-vyvedetna-ulicy-mira-bolee-10-millionov-chelovek.html.

Verdery, K. 1999. The Political Lives of Dead Bodies: Reburial and Postsocialist Change. New York: Columbia University Press.

Vinokurov, A. 2015. “'Bessmertnyi polk'-eto i yest' 'antimaidan." gazeta.ru, 5 June. Retrieved 8 Jan 2016 from http://www.gazeta.ru/ politics/2015/06/04_a_6745762.shtml.

"V Krymu." 2016. "V Krymu novorozhdennym mal'chikam vruchili povestki v armiiu." Moskovskii komsomolets, 29 Feb. Retrieved 15 May 2016 from http://www.mk.ru/social/2016/02/29/v-krymu-novorozhdennym-malchikam-vruchili-povestki-v-armiyu.html.

"Vladimir Putin." 2016. "Vladimir Putin: Pozdravlenie s Dnem Pobedy." Ekho Moskvy, 9 May. Retrieved 7 June 2016 from http://echo.msk.ru/blog/ echomsk/1762136-echo/.

"Vopros dnia." 2015. Komsomol'skaia pravda 51, 12 May.

"V sotssetiakh." 2015. "V sotssetiakh rasskazali o massovke i provokatorakh, primknuvshikh $\mathrm{k}$ shestviiu 'Bessmertnogo polka.'” Novaia gazeta, 11 May. Retrieved from http://www.novayagazeta.ru/news/169369l.html?p=3.

"Vystuplenie." 2016. "Vystuplenie Ministra inostrannykh del Rossii S. V. Lavrova na zasedanii komiteta 'Pobeda', Moskva, 5 aprelia 2016 goda." RF Foreign Ministry official website. 5 April. Retrieved 9 June 2016 from http:// www.mid.ru/foreign_policy/news/-/asset_publisher/cKNonkJE02Bw/ content/id/2208533/pop_up?_101_INSTANCE_cKNonkJE02Bw_ viewMode $=$ tv\&_101_INSTANCE_cKNonkJE02Bw_qrIndex $=0$.

Weiner, A. 2012. Making Sense of War: The Second World War and the Fate of the Bolshevik Revolution. Princeton, NJ, and Oxford: Princeton University Press.

Winter, J. 2006. Remembering War: The Great War between Memory and History in the Twentieth Century. New Haven, CT: Yale University Press.

“Zasedanie". 2015. "Zasedanie Rossiiskogo orgkomiteta 'Pobeda." 17 Mar. Retrieved on 6 June 2016 from: http://special.kremlin.ru/events/ president/news/47867.

Zygar', M. 2016. Vsia kremlevskaia rat'. Kratkaia istoriia sovremennoi Rossii. Moscow: Intellektual'naia literatura. 
Open Access This chapter is licensed under the terms of the Creative Commons Attribution-NonCommercial-NoDerivatives 4.0 International License (http://creativecommons.org/licenses/by-nc-nd/4.0/), which permits any noncommercial use, sharing, distribution and reproduction in any medium or format, as long as you give appropriate credit to the original author(s) and the source, provide a link to the Creative Commons license and indicate if you modified the licensed material. You do not have permission under this license to share adapted material derived from this chapter or parts of it.

The images or other third party material in this chapter are included in the chapter's Creative Commons license, unless indicated otherwise in a credit line to the material. If material is not included in the chapter's Creative Commons license and your intended use is not permitted by statutory regulation or exceeds the permitted use, you will need to obtain permission directly from the copyright holder.

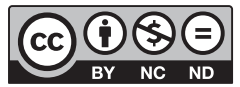

